\title{
Determinan Pengangguran Lulusan SMK di Indonesia Tahun 2020
} Analisis Data Sakernas Februari 2020

\author{
(Determinants of Unemployment of Vocational High School Graduates in Indonesia in 2020) \\ R.BG. Miko Oktavio Wijaya ${ }^{1 *}$, Efri Diah Utami \\ ${ }^{1,2}$ Politeknik Statistika STIS \\ Jalan Otto Iskandardinata No.64C, Jatinegara, Jakarta Timur, Daerah Khusus Ibukota Jakarta 13330

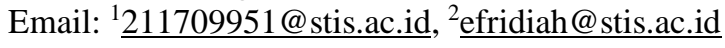

\begin{abstract}
ABSTRAK
Indonesia sedang menghadapi fenomena bonus demografi, tetapi Tingkat Pengangguran Terbuka (TPT) di Indonesia masih tergolong tinggi. Lulusan SMK menjadi kontributor terbesar TPT di Indonesia dalam lima tahun terakhir. Kondisi tersebut tidak sesuai dengan PP No. 17 tahun 2010 yang menyatakan bahwa pendidikan kejuruan bertujuan menciptakan lulusan yang siap bekerja. Penelitian ini bertujuan untuk mengetahui gambaran umum pengangguran lulusan SMK, mengidentifikasi variabel yang menyebabkan pengangguran lulusan SMK serta mengetahui kecenderungan dari variabel yang digunakan. Data yang digunakan adalah data Sakernas Februari 2020. Hasil analisis deskriptif menunjukkan bahwa TPT lulusan SMK tahun 2020 adalah 8,49 persen. Hasil analisis inferensia menggunakan regresi logistik biner menunjukkan bahwa variabel jenis kelamin, gangguan disabilitas, bidang keahlian, tahun kelulusan, dan keikutsertaan pelatihan berpengaruh signifikan terhadap status menganggur lulusan SMK. Kecenderungan lulusan SMK mengalami pengangguran lebih tinggi terjadi pada lulusan laki-laki, tidak memiliki gangguan disabilitas, berasal dari bidang keahlian lainnya, lulus setahun yang lalu, serta tidak mengikuti pelatihan.
\end{abstract}

Kata kunci: TPT, SMK, regresi logistik biner

\section{ABSTRACT}

Indonesia is facing a demographic bonus phenomenon, but the Open Unemployment Rate (TPT) in Indonesia still high. Vocational High School (SMK) graduates have become the biggest contributors to TPT in Indonesia in the last five years. This condition isn't in accordance with PP No. 17 of 2010 which states that vocational education aims to create graduates who are ready to work. This study aims to determine the general description of unemployment for SMK graduates, identify variables that cause unemployment for SMK graduates and determine the trend of the variables used. The data used is Sakernas data in February 2020. The results of the descriptive analysis show that the TPT for SMK graduates in 2020 is 8,49 percent. The results of inferential analysis using binary logistic regression showed that the variables of gender, disability, area of expertise, year of graduation, and participation in training had a significant effect on the unemployed status of SMK graduates. The tendency for SMK graduates to experience unemployment is higher for male graduates, do not have disabilities, come from other fields of expertise, graduated a year ago, and did not attend training.

Keywords: open unemployment rate, vocational high school, binary logistic regression

\section{PENDAHULUAN}

Indonesia sedang menghadapi fenomena bonus demografi yang dapat menjadi sumber pertumbuhan ekonomi bagi suatu negara. Indikasi bonus demografi dapat diketahui dengan adanya penurunan rasio ketergantungan. Hasil Sensus Penduduk 1971 dan Proyeksi Penduduk 2020 menunjukkan bahwa rasio ketergantungan di Indonesia telah mengalami penurunan sebesar 41,4 persen. Bonus demografi dapat menjadi menjadi sumber pertumbuhan ekonomi apabila banyaknya penduduk usia produktif dapat diikuti dengan tingginya produktivitas dari penduduk tersebut (Hayes dan Setyonaluri, 2015). Tingkat produktivitas dapat dilihat berdasarkan angka pengangguran, dimana angka pengangguran yang tinggi mengindikasikan produktivitas yang rendah dari suatu penduduk. BPS (2019) menyebutkan bahwa TPT di Indonesia pada Februari 2019 masih berada di atas 5 persen. Angka tersebut masih tergolong tinggi karena belum memenuhi target dari Rencana Pembanguan Jangka Menengah Nasional (RPJMN) 2015 sampai dengan 2019 yang menargetkan TPT di Indonesia pada tahun 2019 adalah sebesar 4 sampai dengan 5 persen. Jika ditinjau berdasarkan tingkat pendidikan tertinggi yang ditamatkan, lulusan Sekolah Menengah Kejuruan (SMK) merupakan kontributor terbesar TPT di Indonesia dalam lima tahun terakhir. Kondisi ini tidak sesuai dengan PP No. 17 tahun 2010 yang menyatakan bahwa tujuan pendidikan kejuruan adalah untuk menciptakan lulusan yang siap bekerja. 
Mutaqin et al. (2015) menjelaskan jika pengangguran lulusan SMK disebabkan oleh ketidakseimbangan antara jumlah lulusan SMK dengan daya serap industri. Data Kemendikbud menyebutkan bahwa jumlah lulusan SMK di Indonesia dari tahun 2016 sampai dengan 2020 terus mengalami peningkatan. Jumlah lulusan SMK pada tahun 2016 adalah sebanyak 4.222 siswa dan pada tahun 2020 yaitu sebanyak 6.298 siswa. Hal tersebut dapat meningkatkan jumlah pengangguran lulusan SMK jika lapangan pekerjaan yang tersedia tidak dapat mengimbangi jumlah lulusan SMK. Tarma (2016) juga menyebutkan jika pengangguran lulusan SMK diakibatkan oleh adanya kesenjangan antara kualitas lulusan SMK dengan kualitas yang dibutuhkan oleh dunia kerja. Kualitas tersebut dapat berupa karakteristik dari lulusan SMK. Windra (2016) menjelaskan bahwa jenis kelamin dan jurusan SMK berpengaruh signifikan terhadap lama mencari kerja lulusan SMK di Indonesia. Penelitian Prasojo (2020) juga menunjukkan bahwa gangguan disabilitas signifikan mempengaruhi pengangguran. Islamy (2019) menyatakan bahwa variabel tahun kelulusan memiliki pengaruh yang signifikan terhadap pengangguran tamatan SMK di Jawa Barat. Penelitian dari Msigwa dan Kipesha (2013) menunjukkan jika skill atau keterampilan signifikan mempengaruhi pengangguran kaum remaja di Tanzania.

Pemerintah telah melakukan program revitalisasi SMK sejak tahun 2016 dengan tujuan untuk mewujudkan link and match antara sekolah dengan dunia usaha (Khurniawan dan Erda, 2019). Namun sampai saat ini lulusan SMK masih menjadi kontributor terbesar TPT di Indonesia. Melihat hal tersebut maka peneliti tertarik untuk mengidentifikasi variabel yang menyebabkan lulusan SMK di Indonesia mengalami pengangguran. Penelitian ini bertujuan untuk mengetahui gambaran umum dari status menganggur lulusan SMK di Indonesia dan variabel yang diduga mempengaruhinya, mengetahui variabel yang berpengaruh signifikan terhadap status menganggur lulusan SMK, serta untuk mengetahui kecenderungan dari variabel yang signifikan dalam mempengaruhi status menganggur lulusan SMK agar dapat diambil kebijakan yang tepat guna mengurangi potensi meningkatknya jumlah pengangguran serta dampaknya di Indonesia.

\section{METODE}

\section{Landasan Teori dan Kerangka Pikir Penelitian}

Konsep ketenagakerjaan dari International Conference of Labour Statistician (ICLS) 13 membagi angkatan kerja menjadi penduduk berstatus bekerja dan pengangguran. BPS (2019) mendefinisikan bekerja sebagai kegiatan melakukan pekerjaan untuk memperoleh atau membantu memperoleh penghasilan minimal selama satu jam tanpa terputus dalam seminggu yang lalu. Orang yang sementara tidak bekerja juga termasuk ke dalam konsep bekerja. Pengangguran didefinisikan sebagai kondisi dimana angkatan kerja tidak melakukan aktivitas bekerja selama seminggu yang lalu dan sedang mencari pekerjaan atau mempersiapkan usaha. Pengangguran juga mencakup penduduk yang tidak sedang mencari pekerjaan dan mempersiapkan usaha dengan alasan utama sudah diterima bekerja tetapi belum memulainya atau karena merasa putus asa.

Pengangguran lulusan SMK dapat dipengaruhi oleh proses pemilihan karir dari lulusan SMK tersebut. Proses pemilihan karir dapat menentukan apakah lulusan SMK akan bekerja atau tidak bekerja. Teori tentang penentuan karir salah satunya dikemukakan oleh John Krumboltz dengan nama social learning theory of career decision making (SLTCDM). Mictcell dan Krumboltz (1996) menjelaskan jika terdapat empat faktor yang mempengaruhi keputusan pengambilan karir bagi setiap individu. Faktor-faktor tersebut diantaranya adalah sebagai berikut.

1. Faktor sumbangan genetik dan kemampuan khusus, yang merupakan sesuatu yang sudah diwariskan sejak lahir. Sumbangan genetik merujuk pada kecenderungan pekerjaan yang disukai. Contoh sumbangan genetik yaitu jenis kelamin. Sementara itu kemampuan khusus merujuk pada hal yang dapat menjadi keterbatasan pada individu dalam memilih pekerjaan. Contoh dari kemampuan khusus dapat berupa gangguan disabilitas yang dialami oleh seseorang.

2. Faktor kondisi dan kejadian lingkungan, yang merupakan perbedaan kondisi lingkungan dari segi sosial, politik, atau ekonomi. Karakteristik dari faktor ini dapat berupa wilayah tempat tinggal perkotaan dan perdesaan yang memiliki perbedaan kondisi lingkungan.

3. Faktor pengalaman belajar, yang didefinisikan sebagai pengalaman yang telah didapatkan melalui proses pembelajaran dan akan terus bertambah seiring dengan berjalannya waktu. Lulusan SMK telah mendapatkan pengalaman belajar sesuai dengan bidang keahlian yang ditekuninya. Pengalaman belajar juga akan terus bertambah seiring dengan semakin lamanya tahun kelulusan dari lulusan SMK.

4. Faktor keterampilan menyelesaikan tugas, dimana keterampilan dapat diperoleh melalui pelatihan. Keikutsertaan pelatihan pada lulusan SMK dapat meningkatkan keterampilan serta dapat mempengaruhi keputusan karir bagi lulusan SMK. 
Islamy (2019) menjelaskan bahwa jenis kelamin dapat memengaruhi status menganggur, dimana perempuan lebih cenderung mengalami pengangguran karena adanya anggapan bahwa laki-laki lebih kuat dan fleksibel ditempatkan pada berbagai pekerjaan. Prasojo (2020) mamaparkan bahwa gangguan disabilitas berpengaruh terhadap pengangguran, dimana penyandang disabilitas dianggap tidak mampu untuk mandiri karena adanya keterbatasan di dalam diri mereka sehingga lapangan pekerjaan yang tersedia untuk kelompok tersebut relatif terbatas. Penelitian dari Khurniawan et al. (2019) juga menyebutkan bahwa bidang keahlian dari lulusan SMK dapat mempengaruhi keterserapannya ke dalam dunia kerja, dimana lulusan SMK dari bidang keahlian yang banyak dibutuhkan dalam dunia kerja akan cenderung lebih mudah mendapatkan pekerjaan. Wicaksonoputro dan Indrayanti (2017) menyatakan jika tahun kelulusan dapat mempengaruhi pengangguran lulusan SMK, dimana terdapat jeda waktu bagi lulusan SMK yang baru lulus untuk bisa terserap ke dalam dunia kerja. Keikutsertaan pelatihan juga dapat berpengaruh terhadap pengangguran lulusan SMK. Hasyim (2016) menjelaskan bahwa pelatihan kerja mampu meningkatkan keterampilan. Seseorang dengan keterampilan tinggi akan semakin efektif dan efisien dalam menyelesaikan suatu pekerjaan sehingga peluang untuk bisa mendapatkan pekerjaan juga semakin besar. Sementara itu hasil penelitian dari Wardhana et al. (2019) menjelaskan jika lokasi tempat tinggal tidak berpengaruh terhadap pengangguran penduduk usia muda di Jawa Barat. Berdasarkan paparan tersebut, maka kerangka pikir yang terbentuk pada penelitian ini adalah sebagai berikut.

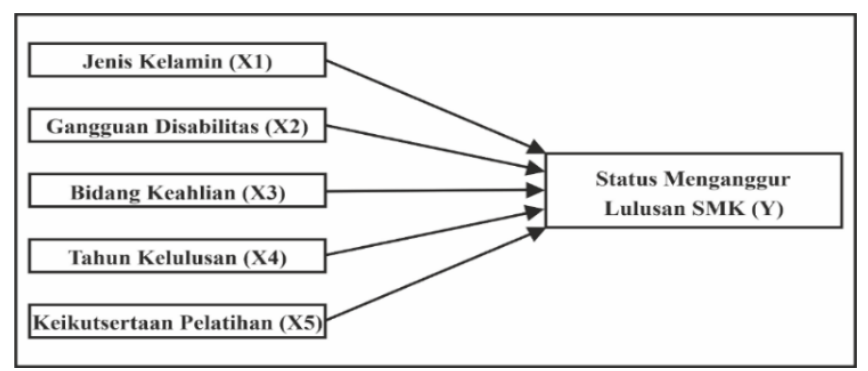

Gambar 1. Kerangka Pikir Penelitian

Berdasarkan kerangka pikir di atas, maka hipotesis pada penelitian ini adalah sebagai berikut.

1. Jenis kelamin berpengaruh terhadap status menganggur pada lulusan SMK.

2. Gangguan disabilitas berpengaruh terhadap status menganggur pada lulusan SMK.

3. Bidang keahlian yang ditekuni berpengaruh terhadap status menganggur pada lulusan SMK.

4. Tahun kelulusan berpengaruh terhadap status menganggur pada lulusan SMK.

5. Keikutsetaan dalam pelatihan berpengaruh terhadap status menganggur pada lulusan SMK.

\section{Cakupan Penelitian}

Penelitian ini menggunakan raw data Survei Angkatan Kerja Nasional (Sakernas) periode Februari 2020. Unit analisis pada penelitian ini adalah angkatan kerja di Indonesia yang merupakan lulusan SMK. Dari total 203.501 sampel yang diwawancarai pada Sakernas Februari 2020, terdapat sebanyak 13.705 sampel yang merupakan angkatan kerja lulusan SMK. Variabel yang digunakan terdiri dari variabel dependen dan variabel independen. Rangkuman pengkategorian variabel pada penelitian ini ditampilkan pada Tabel 1 sebagai berikut.

\begin{tabular}{|c|c|c|c|c|}
\hline Variabel & Nama Variabel & Kategori & Nilai & Variabel Dummy \\
\hline $\mathrm{Y}$ & Status Menganggur & $\begin{array}{l}1: \text { Bekerja* } \\
2: \text { Pengangguran }\end{array}$ & $\begin{array}{l}0 \\
1\end{array}$ & \\
\hline $\mathrm{X}_{1}$ & Jenis Kelamin & $\begin{array}{l}1: \text { Perempuan } \\
2: \text { Laki-laki* }\end{array}$ & $\begin{array}{l}1 \\
0\end{array}$ & $\mathrm{D}_{1}$ \\
\hline $\mathrm{X}_{2}$ & Gangguan Disabilitas & $\begin{array}{l}1: \text { Ada gangguan disabilitas } \\
2: \text { Tidak ada gangguan disabilitas* }\end{array}$ & $\begin{array}{l}1 \\
0\end{array}$ & $\mathrm{D}_{2}$ \\
\hline $\mathrm{X}_{3}$ & Bidang Keahlian & $\begin{array}{l}1: \text { Teknologi dan Rekayasa } \\
2: \text { Bisnis dan Manajemen } \\
3: \text { Lainnya* }\end{array}$ & $\begin{array}{ll}1 & 0 \\
0 & 1 \\
0 & 0\end{array}$ & $\begin{array}{l}D_{31} \\
D_{32}\end{array}$ \\
\hline $\mathrm{X}_{4}$ & Tahun Kelulusan & $\begin{array}{l}1: \text { Lulus setahun yang lalu } \\
2: \text { Lulus lebih dari setahun yang lalu* }\end{array}$ & $\begin{array}{l}1 \\
0\end{array}$ & $\mathrm{D}_{4}$ \\
\hline $\mathrm{X}_{5}$ & Keikutsertaan Pelatihan & $\begin{array}{l}1: \text { Tidak mengikuti pelatihan } \\
2: \text { Mengikuti pelatihan* }\end{array}$ & $\begin{array}{l}1 \\
0\end{array}$ & $\mathrm{D}_{5}$ \\
\hline
\end{tabular}




\section{Metode Analisis}

Analisis pada penelitian ini terdiri dari analisis deskriptif dan analisis inferensia. Analisis deskriptif disajikan dalam bentuk grafik dan tabel guna memperoleh gambaran umum status menganggur lulusan SMK dan variabel yang diduga memengaruhinya. Analisis inferensia dilakukan untuk mengidentifikasi variabel independen yang berpengaruh signifikan terhadap status menganggur lulusan SMK serta untuk mengetahui kecenderungan dari variabel independen yang signifikan. Penelitian ini menggunakan metode analisis berupa regresi logistik biner. Hosmer dan Lemeshow (2000) menjelaskan bahwa persamaan umum dari model regresi logistik biner adalah sebagai berikut.

$$
\hat{g}(x)=\hat{\beta}_{0}+\hat{\beta}_{1} D_{1}+\hat{\beta}_{2} D_{2}+\hat{\beta}_{3} D_{31}+\hat{\beta}_{4} D_{32}+\hat{\beta}_{5} D_{4}+\hat{\beta}_{6} D_{5}
$$

dimana:

$\hat{\beta}_{0}=$ intercept

$\hat{\beta}_{j}=$ koefisien dari parameter ke- $j$ dengan $j=1,2,3, \ldots, 6$

$D$ = variabel dummy

Hosmer dan Lemeshow (2000) juga menjelaskan bahwa tahapan analisis pada regresi logistik biner adalah sebagai berikut.

1. Uji Parameter Secara Simultan

Hipotesis:

$H_{0}: \beta_{1}=\beta_{2}=\beta_{4}=\beta_{4}=\beta_{5}=\beta_{6}=0$ (tidak terdapat pengaruh secara simultan antara variabel independen terhadap status menganggur lulusan SMK)

$H_{1}$ : minimal terdapat satu $\beta_{j} \neq 0$ dengan $j=1,2,3,4,5,6$ (minimal ada satu variabel independen yang berpengaruh signifikan terhadap status menganggur lulusan SMK)

Statistik uji:

$G=-2 \ln \left[\frac{l_{0}}{l_{1}}\right]$

dimana:

$l_{0}=$ nilai likelihood dari model tanpa variabel independen

$l_{1}=$ nilai likelihood dengan seluruh variabel independen

Keputusan: Tolak $H_{0}$ jika nilai $G>\chi_{(0,05 ; 6)}$ atau $p$-value $<0,05$

Kesimpulan: Dengan tingkat signifikansi 5 persen, minimal terdapat satu variabel independen yang berpengaruh signifikan terhadap status menganggur lulusan SMK.

2. Uji Parameter Secara Parsial

Hipotesis:

$H_{0}: \beta_{j}=0$ (tidak ada pengaruh yang signifikan antara variabel independen ke-j terhadap status menganggur lulusan SMK)

$H_{1}: \beta_{j} \neq 0$ (terdapat pengaruh yang signifikan antara variabel independen ke-j terhadap status menganggur lulusan SMK)

Statistik uji:

$W_{j}=\left[\frac{\widehat{\beta}_{j}}{\operatorname{se}\left(\widehat{\beta}_{j}\right)}\right]^{2}$

dimana:

$\hat{\beta}_{j} \quad=$ penduga parameter $\beta_{j}$

$\operatorname{se}\left(\hat{\beta}_{j}\right)=$ standard error dari $\hat{\beta}_{j}$ dimana $j=1,2,3,4,5,6$

Keputusan: Tolak $H_{0}$ jika $W>\chi_{(0,05 ; 1)}^{2}$ atau $p$-value $<0,05$

Kesimpulan: Dengan tingkat signifikansi 5 persen, terdapat pengaruh yang signifikan dari variabel independen ke-j terhadap status menganggur lulusan SMK.

3. Uji Kesesuaian Model

Hipotesis:

$H_{0}$ : Model fit

$H_{1}$ : Model tidak fit

Statistik uji:

$\hat{C}=\sum_{k=1}^{g}\left[\frac{\left(o_{k}-n^{\prime}{ }_{k} \bar{\pi}_{k}\right)^{2}}{n^{\prime}{ }_{k} \bar{\pi}_{k}\left(1-\bar{\pi}_{k}\right)}\right]$ 
dimana:

$\hat{C}=$ Hosmer and Lemeshow test (goodness of fit)

$o_{k}=$ jumlah nilai variabel independen pada kelompok ke-k

$n^{\prime}{ }_{k}=$ jumlah observasi dalam kelompok ke-k

$\bar{\pi}_{k}=$ rata-rata peluang estimasi untuk kelompok ke-k

$g=$ banyaknya kelompok

Keputusan: Tolak $H_{0}$ jika $\hat{C}>\chi^{2}{ }_{0,05 ; 5}$ atau $p$-value $<0,05$

Kesimpulan: Dengan tingkat signifikansi 5 persen, model yang terbentuk tidak fit. Keputusan yang diharapkan adalah gagal tolak $H_{0}$, sehingga model yang terbentuk fit.

4. Analisis Kekuatan Prediksi Model

Kekuatan prediksi model dapat dilihat dari hasil tabel klasifikasi (Agresti, 2002). Tabel klasifikasi terdiri dari tiga komponen yaitu nilai overall percentage, nilai sensitivity, dan nilai specificity. Kekuatan prediksi model dapat ditentukan oleh nilai cut off point (c) yang digunakan, dimana nilai c optimum akan menghasilkan kekuatan prediksi model yang maksimal. Nilai c optimum merupakan cut off yang memiliki jumlah nilai sensitivity dan spescificity paling tinggi. Nilai c optimum dapat dicari dengan analisis kurva Receiver Operating Characteristics (ROC).

5. Interpretasi Nilai Rasio Kecenderungan (Odds Ratio)

Odds ratio adalah nilai yang menyatakan besarnya kecenderungan lulusan SMK untuk mengalami pengangguran dengan nilai kecenderungan sebesar exp $\left(\hat{\beta}_{j}\right)$. Jika nilai kecenderungan kurang dari 1 maka nilai odds ratio menjadi $1 / \exp \left(\hat{\beta}_{j}\right)$, sehingga interpretasi dari nilai tersebut menjadi kecenderungan lulusan SMK untuk dapat bekerja.

\section{HASIL DAN PEMBAHASAN}

\section{Gambaran Umum Status Menganggur Lulusan SMK di Indonesia Tahun 2020 dan Variabel- Variabel yang Diduga Mempengaruhinya}

Gambar 2 menunjukkan bahwa pengangguran lulusan SMK di Indonesia pada tahun 2020 adalah sebesar 8,49 persen. Persentase tersebut terus mengalami penurunan dalam lima tahun terakhir, tetapi lulusan SMK masih tetap menjadi kontributor terbesar TPT di Indonesia. TPT di Indonesia pada Februari 2020 adalah sebesar 4,99 persen (BPS, 2020b). Angka tersebut masih berada di atas target RPJMN 2020 sampai dengan 2024 yang menargetkan TPT di Indonesia pada tahun 2024 adalah sebesar 4 sampai dengan 4,6 persen. Hal ini mengindikasikan bahwa persentase pengangguran lulusan SMK sebagai kontributor terbesar TPT di Indonesia masih tergolong tinggi dan harus diturunkan agar TPT di Indonesia pada tahun 2024 bisa mencapai target RPJMN.

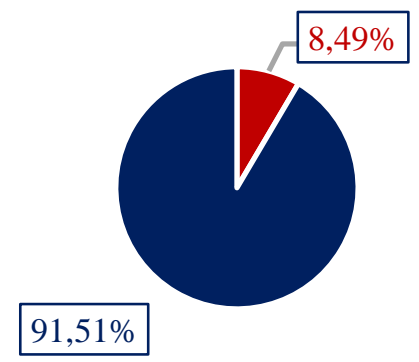

- Pengangguran

- Bekerja

Sumber: Sakernas Februari 2020 (data diolah)

Gambar 2. Persentase pengangguran lulusan SMK di Indonesia tahun 2020

Tabel 2 menggambarkan distribusi persentase pengangguran lulusan SMK di Indonesia berdasarkan variabel independen. Lulusan SMK di Indonesia didominasi oleh lulusan berjenis kelamin laki-laki. Hal ini dapat terjadi karena mayoritas lulusan SMK berasal dari bidang keahlian teknologi dan rekayasa yang merupakan bidang keahlian yang lebih lazim untuk ditekuni oleh laki-laki. Lulusan SMK yang memilki gangguan disabilitas hanya sebesar 2 persen, artinya mayoritas lulusan SMK di Indonesia mampu untuk beraktivitas normal tanpa suatu gangguan apapun. Hampir setengah dari total lulusan SMK di Indonesia berasal dari bidang keahlian teknologi dan rekayasa. Hal tersebut dapat terjadi karena bidang keahlian tersebut memiliki total 13 
jurusan dan merupakan yang paling banyak jika dibandingkan dengan bidang keahlian lainnya. Lulusan SMK yang lulus dalam setahun yang lalu adalah sebesar 3,97 persen, yang artinya lulusan SMK yang lulus pada tahun 2019 hanya sebesar 3,97 persen sementara sisanya lulus sebelum tahun 2019. Mayoritas lulusan SMK juga belum pernah mengikuti pelatihan saat menjalani pendidikan SMK. Hal ini mengindikasikan bahwa tingkat ketertarikan siswa SMK untuk mengikuti pelatihan masih relatif rendah. Jika dilihat berdasarkan tingkat penganggurannya, pengangguran lulusan SMK lebih banyak terjadi pada lulusan SMK berjenis kelamin laki-laki, tidak memiliki gangguan disabilitas, berasal dari bidang keahlian lainnya, lulus dalam setahun yang lalu, serta tidak pernah mengikuti pelatihan.

Tabel 2. Distribusi Persentase Pengangguran Lulusan SMK di Indonesia Menurut Variabel Independen Penelitian

\begin{tabular}{|c|c|c|c|}
\hline \multirow{2}{*}{ Variabel } & \multicolumn{2}{|c|}{ Status Pekerjaan (\%) } & \multirow{2}{*}{ Total N (\%) } \\
\hline & Pengangguran & Bekerja & \\
\hline \multicolumn{4}{|l|}{ Jenis kelamin } \\
\hline Perempuan & 8,12 & 91,88 & $5.237 .300(30,96)$ \\
\hline Laki-laki & 8,65 & 91,35 & $11.680 .290(69,04)$ \\
\hline \multicolumn{4}{|l|}{ Gangguan disabilitas } \\
\hline Ada & 5,94 & 94,06 & $337.654(2,00)$ \\
\hline Tidak ada & 8,54 & 91,46 & $16.579 .936(98,00)$ \\
\hline \multicolumn{4}{|l|}{ Bidang keahlian } \\
\hline Teknologi dan rekayasa & 8,13 & 91,87 & $8.056 .014(47,62)$ \\
\hline Bisnis dan manajemen & 7,45 & 92,55 & $4.959 .836(29,32)$ \\
\hline Lainnya & 10,53 & 89,47 & $3.901 .740(23,06)$ \\
\hline \multicolumn{4}{|l|}{ Tahun kelulusan } \\
\hline Setahun yang lalu & 31,60 & 68,40 & $671.874(3,97)$ \\
\hline Lebih dari setahun yang lalu & 7,53 & 92,47 & $16.245 .716(96,03)$ \\
\hline \multicolumn{4}{|l|}{ Keikutsertaan pelatihan } \\
\hline Tidak mengikuti & 8,91 & 91,09 & $14.308 .526(84,58)$ \\
\hline Mengikuti & 6,16 & 93,84 & $2.609 .064(15,42)$ \\
\hline
\end{tabular}

Variabel-Variabel yang Berpengaruh Signifikan Terhadap Status Menganggur Lulusan SMK di Indonesia Tahun 2020

Hasil analisis regresi logistik biner pada lampiran 1 menunjukkan bahwa pada uji parameter secara simultan didapatkan nilai $G$ sebesar 334,038. Nilai tersebut lebih besar dari nilai $\chi_{(0,05 ; 6)}^{2}$ sebesar 11,070. Nilai $p$-value yang didapatkan juga kurang dari alfa $(0,05)$ sehingga keputusan yang didapatkan adalah tolak $H_{0}$. Kesimpulan dari uji simultan yaitu dengan tingkat signifikansi 5 persen, minimal terdapat satu variabel independen yang berpengaruh signifikan terhadap status menganggur lulusan SMK di Indonesia pada tahun 2020. Hasil uji parameter secara parsial pada lampiran 2 menunjukkan bahwa variabel jenis kelamin, gangguan disabilitas, bidang keahlian, tahun kelulusan, dan keikutsertaan pelatihan berpengaruh signifikan terhadap status menganggur lulusan SMK. Model regresi logistik biner yang terbentuk berdasakan hasil pada uji parsial adalah sebagai berikut.

dimana:

$$
\hat{g}(x)=-2,744-0,165 D_{1}{ }^{* *}-0,597 D_{2}{ }^{*}-0,273 D_{31}{ }^{*}-0,312 D_{32}{ }^{*}+1,886 D_{4}{ }^{*}+0,413 D_{5}{ }^{*}
$$

$D_{1}:$ Jenis kelamin

$D_{2}$ : Gangguan disabilitas

$D_{31}$ : Bidang keahlian teknologi dan rekayasa

$D_{32}$ : Bidang keahlian bisnis dan manajemen

$D_{4}$ : Tahun kelulusan

$D_{5}$ : Keikutsertaan pelatihan

$*$ : Variabel yang berpengaruh signifikan pada alfa $=0,05$

$* *$ : Variabel yang berpengaruh signifikan pada alfa $=0,10$

Hasil uji kesesuaian model pada lampiran 3 menunjukkan bahwa nilai nilai $p$-value yang diperoleh adalah sebesar 0,574 dan lebih besar dari alfa $(0,05)$. Keputusan yang diambil adalah gagal tolak $H_{0}$ yang artinya dengan tingkat signifikansi 5 persen, model yang terbentuk fit atau sudah sesuai dalam menjelaskan status menganggur lulusan SMK di Indonesia pada tahun 2020. Kemudian dilakukan analisis kekuatan prediksi model untuk mengukur kemampuan model dalam mengklasifikasikan observasi dengan tepat. Hasil tabel klasifikasi dengan cut off point sebesar 0,5 menunjukkan bahwa model dapat mengklasifikasikan seluruh 
observasi dengan tepat sebesar 92,5 persen. Angka tersebut tergolong tinggi, namun terdapat ketimpangan yang besar antara nilai sensitivity dan specificity yang dihasilkan, dimana nilai sensitivity yaitu sebesar 0 persen sementara nilai specificity sebesar 100 persen. Analisis kurva ROC dilakukan untuk mendapatkan nilai cut off point (c) optimum yang dapat mengurangi ketimpangan antara nilai sensitivity dan specificity. Hasil analisis kurva ROC menunjukan bahwa nilai c optimum yang didapatkan adalah sebesar 0,072. Angka tersebut kemudian digunakan untuk melakukan analisis kekuatan prediksi model kembali. Hasil tabel klasifikasi menggunakan cut off point sebesar 0,072 ditunjukkan pada Tabel 3 sebagai berikut.

Tabel 3. Hasil tabel klasifikasi dengan cut off point 0,072

\begin{tabular}{|c|c|c|c|c|}
\hline \multirow{3}{*}{ Observed } & & \multicolumn{2}{|c|}{ Predicted } & \multirow{3}{*}{ Percentage Correct } \\
\hline & & \multicolumn{2}{|c|}{$\begin{array}{l}\text { Status Menganggur } \\
\text { Lulusan SMK }\end{array}$} & \\
\hline & & Bekerja & Pengangguran & \\
\hline & Bekerja & 9.879 & 2.795 & 77,9 \\
\hline Status Menganggur Lulusan SMK & Pengangguran & 628 & 403 & 39,1 \\
\hline \multicolumn{4}{|c|}{ Overall Percentage } & 75,0 \\
\hline
\end{tabular}

Persentase total ketepatan klasifikasi adalah sebesar 75 persen. Nilai sensitivity sebesar 39,1 persen menunjukkan bahwa model dapat memprediksi lulusan SMK yang berstatus menganggur dengan tepat sebesar 39,1 persen. Nilai specificity sebesar 77,9 persen berarti bahwa model dapat memprediksi lulusan SMK yang berstatus bekerja dengan tepat sebesar 77,9 persen. Ketimpangan antara nilai sensitivity dan specificity telah berkurang sehingga kekuatan prediksi dari model dapat dikatakan lebih baik.

\section{Kecenderungan Variabel Independen dalam Mempengaruhi Status Menganggur Lulusan SMK di Indonesia Tahun 2020}

Interpretasi dari nilai odds ratio pada setiap variabel independen adalah sebagai berikut.

\section{Jenis Kelamin}

Nilai odds ratio pada variabel ini adalah 0,848 yang artinya lulusan SMK perempuan memiliki kecenderungan untuk berstatus menganggur 0,848 kali lebih kecil dibandingkan dengan lulusan laki-laki. Lulusan SMK laki-laki memiliki kecenderungan lebih besar untuk berstatus menganggur. Hasil tersebut tidak sejalan dengan penelitian Islamy (2019) yang menunjukkan bahwa lulusan SMK laki-laki memiliki kecenderungan lebih kecil untuk mengalami pengangguran. Kondisi ini dapat terjadi karena jumlah lulusan laki-laki lebih banyak dari lulusan perempuan sehingga persaingan untuk dapat terserap ke dalam dunia kerja cenderung lebih ketat. Mutaqin et al. (2015) menjelaskan bahwa pengangguran lulusan SMK terjadi karena adanya ketidakseimbangan antara daya serap industri dengan jumlah lulusan SMK di Indonesia. BPS (2020b) menyebutkan bahwa TPT pada perempuan terus mengalami penurunan dari Februari 2018 sampai dengan Februari 2020. Hal ini mengindikasikan bahwa semakin lama semakin banyak lapangan pekerjaan yang tersedia untuk perempuan sehingga jumlah perempuan yang bisa bekerja juga semakin bertambah.

\section{Gangguan Disabilitas}

Nilai odds ratio pada variabel ini yaitu sebesar 0,550 yang artinya lulusan SMK dengan gangguan disabilitas memiliki kecenderungan untuk berstatus menganggur 0,550 kali lebih kecil dibandingkan lulusan SMK tanpa gangguan disabilitas. Dengan kata lain lulusan SMK tanpa gangguan disabilitas memiliki kecenderungan lebih besar untuk berstatus menganggur. Hasil tersebut tak sejalan dengan hasil penelitian Prasojo (2020) yang menyebutkan bahwa tenaga kerja yang bukan penyandang disabilitas lebih cenderung untuk dapat bekerja dibandingkan tenaga kerja penyandang disabilitas. Kondisi ini menunjukkan bahwa lapangan pekerjaan untuk para penyandang disabilitas tetap tersedia. Perlindungan kesempatan kerja bagi tenaga kerja penyandang disabilitas juga sudah diakui dan dilindungi oleh undang-undang. Undang-Undang Nomor 13 Tahun 2003 Pasal 5 menjelaskan jika setiap tenaga kerja memiliki kesempatan yang sama tanpa diskriminasi untuk memperoleh pekerjaan. Lulusan SMK dengan gangguan disabilitas juga dianggap mampu untuk tetap bersaing di dalam dunia kerja meskipun terdapat gangguan di dalam dirinya.

\section{Bidang Keahlian}

Nilai odds ratio pada kategori teknologi dan rekayasa adalah sebesar 0,761 yang artinya lulusan SMK dari bidang keahlian teknologi dan rekayasa memiliki kecenderungan untuk berstatus menganggur 0,761 kali lebih kecil dibandingkan lulusan dari bidang keahlian lainnya. Kategori bisnis dan manajemen memiliki nilai odds ratio sebesar 0,732 yang berarti bahwa lulusan SMK dari bidang keahlian bisnis dan manajemen memiliki 
kecenderungan untuk berstatus menganggur 0,732 kali lebih kecil dibandingkan lulusan dari bidang keahlian lainnya. Hasil tersebut mengindikasikan bahwa lulusan SMK yang berasal dari bidang keahliannya lainnya memiliki kecenderungan lebih besar untuk berstatus menganggur. Hasil ini sejalan dengan hasil penelitian dari Khurniawan et al. (2019) yang menjelaskan bahwa empat jurusan SMK yang menjadi penghasil jumlah pekerja tertingi di Indonesia adalah jurusan yang berasal dari bidang keahlian teknologi dan rekayasa serta bisnis dan manajemen. Hal tersebut menunjukkan bahwa bidang keahlian teknologi dan rekayasa serta bisnis dan manajemen merupakan bidang keahlian yang memiliki banyak peminat serta mempunyai daya saing yang tinggi di dalam dunia kerja sehingga lulusan SMK yang berasal dari bidang keahlian tersebut memiliki peluang yang lebih besar untuk dapat bekerja.

\section{Tahun Kelulusan}

Variabel tahun kelulusan memiliki nilai odds ratio sebesar 6,591. Angka tersebut berarti bahwa lulusan SMK yang lulus dalam setahun yang lalu memiliki kecenderungan untuk berstatus menganggur 6,591 kali lebih besar dibandingkan lulusan SMK yang lulus lebih dari setahun yang lalu. Hasil penelitian dari Wicaksonoputro dan Indrayanti (2017) menunjukkan hasil yang sejalan dengan penelitian ini. Hal tersebut mengindikasikan bahwa di dalam dunia kerja terdapat waktu tunggu bagi seorang lulusan untuk bisa mendapatkan pekerjaan. Mitchell dan Krumboltz (1996) menjelaskan jika pengalaman belajar akan terus bertambah seiring dengan berjalannya waktu. Lulusan yang lulus lebih dari setahun yang lalu memiliki pengalaman yang lebih banyak dalam memilih pekerjaan dibandingkan lulusan yang lulus dalam setahun yang lalu sehingga hal tersebut dapat berpengaruh terhadap keterserapannya di dalam dunia kerja.

\section{Keikutsertaan Pelatihan}

Nilai odds ratio pada variabel ini yaitu sebesar 1,511 dan dapat diartikan bahwa lulusan SMK yang tidak pernah mengikuti pelatihan memiliki kecenderungan untuk berstatus menganggur 1,511 kali lebih besar dibandingkan dengan lulusan yang pernah mengikuti pelatihan. Hasil penelitian dari Hasyim (2016) menyebutkan jika angkatan kerja terdidik yang belum pernah mengikuti pelatihan kerja memiliki kecenderungan lebih besar untuk menjadi pengangguran. Hasil penelitian Hasyim (2016) sejalan dengan hasil pada penelitian ini sehingga dapat disimpulkan bahwa pelatihan dapat meningkatkan keterampilan seseorang serta dapat membantu seseorang untuk mendapatkan pekerjaan. Lulusan SMK yang memiliki keterampilan tinggi akan semakin efektif dan efisien dalam menyelesaikan suatu pekerjaan sehingga peluang untuk bisa mendapatkan pekerjaan juga semakin besar.

\section{KESIMPULAN}

Berdasarkan hasil di atas, dapat disimpulkan bahwa persentase pengangguran lulusan SMK di Indonesia pada tahun 2020 adalah sebesar 8,49 persen, dimana angka tersebut masih tergolong tinggi. Mayoritas provinsi di Indonesia memiliki persentase pengangguran lulusan SMK di bawah persentase nasional. Lulusan SMK didominasi oleh lulusan laki-laki, tidak memiliki gangguan disabilitas, berasal dari bidang keahlian lainnya, lulus lebih dari setahun yang lalu, dan tidak pernah mengikuti pelatihan. Pengangguran lulusan SMK di Indonesia didominasi oleh lulusan SMK berjenis kelamin laki-laki, tidak memiliki gangguan disabilitas, berasal dari bidang keahlian lainnya, lulus dalam setahun yang lalu, serta tidak pernah mengikuti pelatihan.

Variabel jenis kelamin, gangguan disabilitas, bidang keahlian, tahun kelulusan, dan keikutsertaan pelatihan berpengaruh signifikan terhadap status menganggur lulusan SMK. Lulusan SMK yang memiliki kecenderungan lebih besar untuk berstatus menganggur adalah lulusan SMK yang berjenis kelamin laki-laki, tidak memiliki gangguan disabilitas, berasal dari bidang keahlian lainnya, lulus dalam setahun yang lalu, serta tidak pernah mengikuti pelatihan. Lulusan dengan gangguan disabilitas memiliki kecenderungan lebih kecil untuk berstatus menganggur. Hal tersebut mengindikasikan bahwa kesempatan kerja untuk penyandang disabilitas tetap terbuka luas dan telah dilindungi oleh undang-undang.

\section{DAFTAR PUSTAKA}

Agresti, A. (2002). Categorical Data Analysis: Second Edition. Florida: Wiley-Interscience.

Badan Perencanaan Pembangunan Nasional. (2014). Rencana Pembangunan Jangka Menengah Nasional (RPJMN) 2015-2019. Jakarta: Badan Perencanaan Pembangunan Nasional.

Badan Perencanaan Pembangunan Nasional. (2019). Rencana Pembangunan Jangka Menengah Nasional (RPJMN) 2020-2024. Jakarta: Badan Perencanaan Pembangunan Nasional.

Badan Pusat Statistik. (2011). Umur dan Jenis Kelamin Penduduk Indonesia Hasil Sensus Penduduk 2010. Jakarta: Badan Pusat Statistik. 
Badan Pusat Statistik . (2018). Proyeksi Penduduk Indonesia Hasil SUPAS 2015. Jakarta: Badan Pusat Statistik.

Badan Pusat Statistik. (2019). Pedoman Pencacah Survei Angkatan Kerja Nasional Agustus 2019. Jakarta: Badan Pusat Statistik.

Badan Pusat Statistik. (2020a). Booklet Sakernas Februari 2020. Jakarta: Badan Pusat Statistik.

Badan Pusat Statistik. (2020b). Keadaan Ketenagakerjaan Indonesia Februari 2020. Jakarta: Badan Pusat Statistik

Franita, R. (2016). Analisa Pengangguran di Indonesia. Jurnal Ilmu Pengetahuan Sosial Volume 1, 88-93.

Hasyim, M. N. (2016). Pengaruh Karakteristik Sosial Demografi dan Ekonomi terhadap Status Pengangguran pada Angkatan Kerja Terdidik di Provinsi Aceh Tahun 2015 [Skripsi]. Jakarta: Sekolah Tinggi Ilmu Statistik.

Hayes, A., \& Setyonaluri, D. (2015). Taking Advantage of The Demographic Divident in Indonesia. Jakarta: UNFPA Indonesia.

Hosmer, D. W., \& Lemeshow, S. (2000). Applied Logistics Regression Second Edition. New York: A WileyInterscience Publication.

Indrayanti, R. (2018). Pengaruh Kesesuaian Bidang Studi dan Pelatihan Kerja terhadap Lama Mencari Kerja Pekerja Muda Berpendidikan SMK. Researchgate, 1-11.

Islamy, A. P. (2019). Faktor-faktor yang Mempengaruhi Tamatan SMK Menganggur di Provinsi Jawa Barat [Skripsi]. Jakarta: Politeknik Statistika STIS.

Jati, W. R. (2015). Bonus Demografi Sebagai Mesin Pertumbuhan Ekonomi. Populasi Volume 23 Nomor 1, $1-19$.

Khurniawan, A. W., \& Erda, G. (2019). Peningkatan Mutu Pendidikan SMK Melalui Revitalisasi Berkelanjutan. Jurnal Vocational Education Policy Volume 1 Nomor 19, 1-11.

Khurniawan, A. W., Erda, G., \& Majid, M. A. (2019). Profil Lulusan SMK terhadap Tingkat Penyerapan Tenaga Kerja di Indonesia Tahun 2018/2019. Jurnal Vocational Education Policy Volume 1 Nomor 9, 15.

Maryati, S. (2015). Dinamika Pengangguran Terdidik: Tantangan Menuju Bonus Demografi di Indonesia. Journal of Economic and Economic Education Volume 3 Nomor 2, 124-136.

Mitchell, L. K., \& Krumboltz, J. D. (1996). Krumboltz's Learning Theory of Career Choice and Counseling. San Francisco: Jossey Bass.

Msigwa, R., \& Kipesha, E. F. (2013). Determinants of Yotuh Unemployment in Developing Country: Evidences from Tanzania. Journal of Economics and Sustainable Development Volume 4 Nomor 14, 6776.

Mutaqin, M. K., Kusnawa, W. S., \& Sriyono. (2015). Studi Eksplorasi Keterserapan Lulusan Sekolah Menengah Kejuruan Negeri di Kota Bandung pada Industri Otomotif. Journal of Mechanical Engineering Education Volume 2 Nomor 2, 247-252.

Nugroho, R. E. (2013). Peningkatan Kemampuan Pengambilan Keputusan Karir melalui Gyroscope pada Siswa Kelas XII di SMA Negeri 1 Cawas [Skripsi]. Yogyakarta: Universitas Negeri Yogyakarta.

Pemerintah Indonesia . (2003). Undang-undang (UU) tentang Ketenagakerjaan. Jakarta: Badan Pemeriksa Keuangan Republik Indonesia.

Pemerintah Indonesia. (2010). Peraturan Pemerintah (PP) tentang Pengelolaan dan Penyelenggaraan Pendidikan. Jakarta: Badan Pemeriksa Keuangan Republik Indonesia.

Prasojo, P. (2020). Analisis Penyerapan Tenaga Kerja Penyandang Disabilitas di Kabupaten Malang [Skripsi]. Malang: Universitas Brawijaya.

Pusat Data dan Teknologi Informasi (2016). Statistik Pendidikan. Tabel Statistik Sekolah Menengah Kejuruan $\begin{array}{lllllll}(S M K) . & \text { Diakses } & \text { pada } & \text { tanggal } & 25 & \text { Juni } & 2019\end{array}$ http://statistik.data.kemdikbud.go.id/index.php/page/smk

Tarma. (2016). Corporate Vocational School: Strategi Antisipatif Menghadapi Pengangguran Lulusan SMK dalam Perspektif Bonus Demografi. Jurnal Dinamika Manajemen Pendidikan Volume 1 Nomor 1, 1-6.

Wardhana, A., Kharisma, B., \& Ibrahim, Y. F. (2019). Pengangguran Usia Muda di Jawa Barat. Jurnal Ekonomi dan Bisnis Universitas Udayana Volume 8 Nomor 9, 1049-1062.

Wicaksonoputro, H. B., \& Indrayanti, R. (2017). Profil Pengangguran dan Lama Mencari Kerja Lulusan $S M K$. Depok: Lembaga Demografi Fakultas Ekonomi dan Bisnis Universitas Indonesia.

Windra, M. F. (2016). Pengaruh Faktor Demografi, Pendidikan, dan Ketenagakerjaan terhadap Lama Mencari Kerja Lulusan SMK di Indonesia [Skripsi]. Jakarta: Sekolah Tinggi Ilmu Statistik. 


\section{LAMPIRAN}

Lampiran 1. Uji parameter secara simultan

\section{Omnibus Tests of Model Coefficients}

\begin{tabular}{ccc|c|c} 
& & Chi-square & df & Sig. \\
\hline \multirow{3}{*}{ Step 1} & Step & 344.038 & 6 & .000 \\
\cline { 2 - 5 } & Block & 344.038 & 6 & .000 \\
\cline { 2 - 5 } & Model & 344.038 & 6 & .000 \\
\hline
\end{tabular}

Lampiran 2. Uji parameter secara parsial

\begin{tabular}{|c|c|c|c|c|c|c|c|c|c|}
\hline \multicolumn{10}{|c|}{ Variables in the Equation } \\
\hline & & \multirow[b]{2}{*}{$\mathrm{B}$} & \multirow[b]{2}{*}{ S.E. } & \multirow[b]{2}{*}{ Wald } & \multirow[b]{2}{*}{ df } & \multirow[b]{2}{*}{ Sig. } & \multirow[b]{2}{*}{$\operatorname{Exp}(B)$} & \multicolumn{2}{|c|}{ 95\% C.I.for $\operatorname{EXP}(B)$} \\
\hline & & & & & & & & Lower & Upper \\
\hline Step & J_Kelamin(1) & -.165 & .086 & 3.700 & 1 & .054 & .848 & .717 & 1.003 \\
\hline \multirow[t]{7}{*}{$1^{\mathrm{a}}$} & Gangguan disabilitas(1) & -.597 & .275 & 4.705 & 1 & .030 & .550 & .321 & .944 \\
\hline & Bidang Keahlian & & & 16.150 & 2 & .000 & & & \\
\hline & Bidang Keahlian(1) & -.273 & .085 & 10.367 & 1 & .001 & .761 & .644 & .899 \\
\hline & Bidang Keahlian(2) & -.312 & .090 & 12.056 & 1 & .001 & .732 & .614 & .873 \\
\hline & Tahun kelulusan(1) & 1.886 & .099 & 359.429 & 1 & .000 & 6.591 & 5.423 & 8.009 \\
\hline & Keikutsertaan Pelatihan(1) & .413 & .099 & 17.557 & 1 & .000 & 1.511 & 1.246 & 1.833 \\
\hline & Constant & -2.744 & .111 & 606.361 & 1 & .000 & .064 & & \\
\hline
\end{tabular}

a. Variable(s) entered on step 1: J_Kelamin, Gangguan disabilitas, Bidang Keahlian, Tahun kelulusan, Keikutsertaan Pelatihan.

Lampiran 3. Uji kesesuaian model

\section{Hosmer and Lemeshow Test}

\begin{tabular}{cc|c|c} 
Step & Chi-square & df & Sig. \\
\hline 1 & 3.834 & 5 & .574 \\
\hline
\end{tabular}

